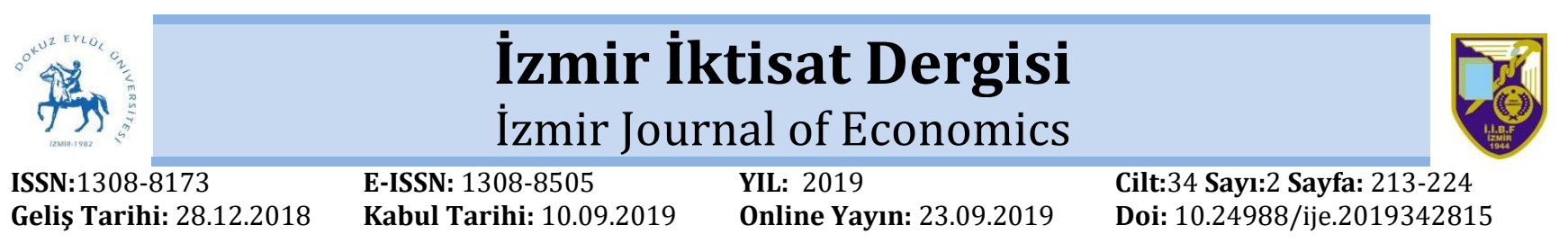

\title{
Birey-Örgüt Uyumu ve Örgütsel Adalet: Uyum Her Zaman İyi midir? ${ }^{1}$
}

\author{
Nihal YAZICI ${ }^{2}$, Senay YÜRÜR ${ }^{3}$
}

Özet

\begin{abstract}
Birey-örgüt uyumu genellikle örgütler için yarattığı olumlu sonuçlar açısından ele alınmaktadır. Acaba bu uyum, çalışanların örgütlerini daha adil algılamalarına da neden olur mu? Eğer öyleyse, bu durum bazı etik tartışmalara yol açar mı? Bu sorulardan yola çıkarak tasarlanan bu araştırmanın temel amacl, birey-örgüt uyumunun çalışanların örgütsel adalet algılarına etkisini analiz etmektir. Bu amaç doğrultusunda Yalova'daki 220 kamu ve özel sektör çalışanına anket uygulanmıştır. Yapılan analizler sonucunda birey-örgüt uyumunun, örgütsel adaletin tüm boyutları üzerinde pozitif etkisi olduğu görülmüştür.
\end{abstract}

Anahtar kelimeler: Örgütsel Adalet, Dağıtım Adaleti, Prosedür Adaleti, Kişilerarası Adalet, Bilgilendirmeye Dayalı Adalet, Birey-Örgüt Uyumu.

Jel Kodu: M10, M12

\section{Person-Organization Fit and Organizational Justice: Is Harmony Always Good?}

Abstract

Person- organization fit is generally considered in terms of positive outcomes for organizations. Do this fit between person and the organization affect organizational justice perception of employees? If so, does this lead to some ethical debate? This research aims to answer the question of "How the person-organization (P-O) fit level effects the organizational justice perceptions?". For the stated purpose, the effect of P-O fit on organizational justice perceptions of employees was tested using survey on 220 employees, including 106 public and 104 private sector employees from Yalova. As a result of the regression analysis, it has been seen that person-organization fit level has positive effect on all organizational justice dimensions.

Keywords: Organizational Justice, Distributive Justice, Procedural Justice, Interpersonal Justice, Informational Justice, Person-Organization Fit.

Jel Codes: M10, M12

\section{GíRİ̧}

Yer aldıkları örgütte kendilerine adil davranılıp davranılmadığına ilişkin çalışan algısı olarak tanımlanan örgütsel adalet (Folger ve Cropanzano, 1998) örgütsel vatandaşlık, örgütsel bağlılık, iş tatmini, performans artışı gibi pek çok olumlu çalışan davranışına yol açtığı için (Moorman, 1991; McFarlin ve Sweeney, 1992; Konovsky ve Organ, 1996; Martin ve Bennett, 1996; Cohen-Charash ve Spector, 2001; Cohen-Charash ve Spector, 2001; Yürür, 2008; Zapata-Phelan vd., 2009; Lavelle vd., 2009) örgütler ve bilim insanları açısından önemle üzerinde durulan bir konudur. Kendilerine adaletsiz davranıldığını düşünen bireylerin üretkenlik karşıtı iş davranışları, misilleme ve hatta hırsızlık (Greenberg, 1990; Skarlicki ve Folger, 1997; Fox vd., 2001) gibi davranışlar sergileyebildiklerinin bilinmesi konuyu daha da önemli hale getirmektedir. Örgütsel adaleti, örgütler tarafından istenen ya da istenmeyen pek çok çalışan davranışının temel sebebi olarak görmek yanlış olmaz. $\mathrm{Bu}$ önemi nedeniyle de adalet algısının nasıl şekillendiğinin, öncüllerinin ve sonuçlarının derinlemesine anlaşlabilmesi gerekmektedir. Ancak hem uluslararası yazında hem de ulusal

\footnotetext{
${ }^{1} \mathrm{Bu}$ çalışma 19-21 Nisan 2018 tarihlerinde Antalya'da düzenlenen İnternatioanal Applied Social Sciences Congress' de sunulan bildirinin genişletilmiş halidir.

${ }^{2}$ Gebze Teknik Üniversitesi, SBE, Doktora Öğrencisi, Gebze/KOCAELİ, nihal.yazici@gtu.edu.tr,

ORCID: 0000-0001-9378-0998

3Prof. Dr., Yalova Üniversitesi, İIBF, İşletme Bölümü, Merkez/YALOVA, senay.yurur@yalova.edu.tr,

ORCID:0000-0002-3859-9827
} 
yazında örgütsel adaletin sonuçlarına yönelik araştırmalarla kıyaslandığında, öncülleri ile ilgili araştırmaların göreli olarak daha az olduğu ifade edilmektedir (Mayer vd., 2007; Yürür, 2015). Diğer bir değișle örgütsel adaleti bağımsız değişken olarak ele alarak, çeșitli örgütsel tutum ve davranışlarla ilişkilendiren çok sayıda araştırma varken, bu algıyı şekillendiren bireysel ve örgütsel değişkenlerin ele alındığı araştırma sayısının daha az olduğu vurgulanmaktadır. Dolayısıyla bu çalışmada örgütsel adalet, öncülleri açısından ele alındığı için elde edilecek sonuçların yazındaki boşluğu doldurmaya yardımcı olabileceği düşünülmektedir.

Ayrıca bu çalışmada birey-örgüt uyumunun örgütsel adalet algısına etkisi, örgütsel adalet yazınında yer alan deontolojik tartışmalara (Cropanzano vd., 2003) işık tutabilmesi amacıyla incelenmektedir. Birey-örgüt uyumunun türlerinden olan bütünleyici uyumla, tarafların 'ne kadar benzer oldukları', ihtiyaç-sunulan uyumuyla da bireyin istek ve ihtiyaçlarının örgüt tarafından ne derecede karşılandığı ölçülmektedir (Meydan, 2019). Yüksek birey-örgüt uyumu adalet algısını artırıyorsa ya da diğer bir ifadeyle eğer birey kendine benzediği için ya da beklentileri karşılandığı için örgütünü daha adil algılıyor ise, bu hem örgütsel adaletin ilgili yazında da belirtildiği gibi öznel bir olgu olduğuna (Folger ve Cropanzano, 1998: Xiii) yeni bir delil olacak, hem de bireyler için adaletin neden önemli olduğu konusuna (örn., kişisel çıkarları için) ışık tutabilecektir. Diğer bir anlatımla bireyler için örgütün adil olması, örgütsel uygulamaların bir takım etik standartla uyumlu olmasına mı, yoksa bu uygulamaların kişisel çıkarları ile uyumlu olmasına mı bağlıdır?

Birey-örgüt arasında uyum olması tarafların lehine olumlu sonuçlar ortaya çıkarabilir, ancak burada araștırmaya konu edilen 'adalet algısı' için durum biraz farklı düşünülmelidir. Yani birey ve örgüt ikilisinde tarafların değerleri ve çlkarları etik standartlara uygun ise buradaki uyum bir tartışmaya meydan vermeyebilir. Ama ya öyle değilse? Ya tarafların uyuşan değerleri etik standartlara aykırı ise? Yine de birey örgütsel değerlere dayalı olarak ortaya çıkan uygulamaları adil algılar mı?

Diğer taraftan birey-örgüt uyumu yazınında, birey-örgüt uyumunun bazı çalışan algı ve tutumları ile ilişkisine odaklanılmasına karşılık, örgütsel adalet ile ilişkisi detaylı bir şekilde incelenmemiştir. Bildiğimiz kadarıyla Türkiye'de spesifik olarak bu konuya odaklanan üç çalışma bulunmaktadır (Çelik vd., 2011; Turunç ve Çelik, 2012; Köksal, 2017). Ancak adı geçen bu çalışmalarda örgütsel adalet ya tek boyutta (dağıtım adaleti) ya da bağımsız değişken olarak ele alınmıștır. Yani burada ele alındığı gibi uyumun adalete etkisine değil, tersine adalet algısının bireyörgüt uyumuna etkisine odaklanılmıştır. $\mathrm{Bu}$ araştırmada ise, uyumu düzeyinin, örgütsel adaletin tüm boyutları üzerindeki etkisinin incelenmesi amaçlanmıştır. Bu iki değişken arasındaki ilişkinin incelenmesi ile de, bireyörgüt uyumu kuramına (Kristof, 1996) olduğu gibi örgütsel adalet yazınındaki bazı model ve yaklaşımlara da katkı sağlanması beklenmektedir.

\section{KAVRAMSAL ÇERÇEVE}

\section{1 Örgütsel adalet}

Örgütsel adalet, örgütsel kaynakların dağıtımı, dağıtım kararlarının verilmesinde uygulanan prosedürler ve bireyler arası ilişkileri belirleyen kuralların adilliğine ilişkin çalışanların algısı olarak tanımlanmaktadır (Folger ve Cropanzano, 1998). Örgütsel adalet genel olarak dağıtım adaleti, prosedür adaleti ve etkileşim adaleti olmak üzere üç boyutta ele alınmaktadır. Dağıtım adaleti çalışanların örgütlerinden elde ettiği kazanımların adil olup olmadığına ilişkin algısı olarak tanımlanmaktadır (Yürür, 2015; 2018). Bireyler katkıları oranında kazanım elde etmek isterler ancak kazanımlarının adil olduğunu algılamaları için katkı-kazanım oranlarının kendileriyle denk gördükleri diğer bireylerinki ile eşit olması gerekmektedir (Adams, 1965). Prosedür adaleti ise kazanımlarla ilgili kararlarda kullanılan yöntemler, mekanizmalar ve süreçlerle ilgili adalete işaret etmektedir 
(Folger ve Cropanzano, 1998). Bu adalet türü, örgütsel karar verme süreçleri ya da performans değerleme sistemleri gibi örgütsel uygulamalarda kullanılan yöntemlerle ilgilidir. Diğer bir adalet türü olan etkileşim adaleti ise örgütteki bireylerarası iletişimin kalitesine yönelik çalışan algısı olarak tanımlanmaktadır (Bies ve Moag, 1986). Etkileşim Adaleti daha sonra Greenberg (1993) tarafindan iki alt kategoride sınıflandırılmıştır. Bunlardan ilki; kararın uygulanmasından sorumlu olan kişilerin, karardan etkilenen bireylere nazik ve saygın davranıp davranmamasına odaklanan kişilerarası adalettir. Diğeri ise, dağıtım kararlarının altında yatan mantığın, karardan etkilenen bireylere açık ve yeterli derecede açıklanıp açıklanmaması ile ilgili olan bilgilendirmeye dayalı adalettir. Buna göre çalışanlar, kendilerine yeterli açılkama yapıldığında istenmeyen bir sonuca karșı daha toleranslı olabilmektedirler (Greenberg, 1990).

\subsection{Birey-örgüt uyumu}

Kristof'a (1996) göre en genel anlamda birey ve örgüt arasındaki 'uyum' şeklinde tanımlanabilecek olan birey-örgüt uyumu kavramı, uyumun konusuna göre farklı kırılımlar gösterebilecektir. Yaygın olarak kullanılan uyum sinıflandirması tamamlayıcı (complementary) ve bütünleyici (supplementary) uyumdur ve konuyla ilgili öne çıkan çalışmalarda da bu ayrımın kullanıldığı belirtilmektedir (Meydan, 2019). Birey-örgüt etkileşiminde, taraflardan birinin ihtiyaç ve beklentilerinin diğeri tarafından karşılanması tamamlayıcı uyum olarak tanımlanmaktadır (Kristof, 1996; Muchinsky ve Monohan, 1987). Bu uyumda vurgulanan, tarafların birbirlerinin eksikliklerini, ihtiyaçlarını ya da taleplerini karşılama düzeyidir. Muchinsky and Monahan (1987) tarafından öncelikle, örgütün talepleri ile bireyin yetenekleri arasındaki uyum olarak ele alınan tamamlayıcı uyum daha sonra, çalışanın ihtiyaçları ve örgütün bu ihtiyaçları karşılama düzeyi arasındaki uyumu da içerecek şekilde genişletilmiştir (Kristof, 1996). Bu nedenle tamamlayıc uyumun talep-yetenek иуити (demands-abilities fit) ve ihtiyaç duyulan-sunulan uyumu (needs-supplies fit) olarak iki alt boyutu bulunmaktadır (Kristof, 1996; Edwards ve Shipp, 2007). Bireyin sahip olduğu yetenekler, örgütün talepleri ile uyuşuyor ise talep-yetenek uyumu ortaya çlkarken, bireyin ihtiyaç, istek ve öncelikleri örgüt tarafından ne kadar karşılanırsa o derecede de ihtiyaç duyulan-sunulan uyumu ortaya çıkmaktadır.

Buna karşıllk bireyin ve örgütün benzer değerleri paylaşması olarak tanımlanan uyum türü ise bütünleyici uyum olarak adlandırılmaktadır (Kristof, 1996; Muchinsky ve Monohan, 1987). Chatman (1989) birey ve örgüt arasındaki istihdam ilişkisinin, bireyin değerlerine ve davranışlarına olan etkisini ve bunun tersine bireyin de örgütsel norm ve değerlerin oluşmasındaki etkisini anlayabilmek için öncelikle bu iki tarafın değerleri arasındaki uzlaşmanın incelenmesi gereğine dikkat çekmektedir. Bu noktadan hareketle de bireyörgüt uyumunu, bireyin sahip olduğu değerler ile örgütsel norm ve değerler arasındaki uyum, benzeşme olarak tanımlamaktadır (Chatman, 1989). Hangi uyum türünün çalışan tutum ve davranışlarını açıklamada daha baskın olduğuna yönelik soruya Cable ve Edwards (2004), her iki uyumun da eşit bir etkiye sahip olduğu yanıtını vermektedir. Bu araştırmacılara göre, psikolojik ihtiyaçların tatmini anlamına gelen tamamlayıcı uyum ve değerlerin uyumu anlamına gelen bütünleyici uyumun her ikisinin yokluğunda da çalışanların iş tatminleri azalmaktadır.

\subsection{Kuramsal arka plan}

Birey-örgüt uyumunun çalışanların örgütsel adalet algılarını etkileyebileceği öngörüsünün kuramsal arka planını birey-örgüt uyumu kuramı (Kristof, 1996) oluşturmaktadır. Bireyörgüt uyumu kuramı, psikolojideki etkileşimci perspektifin bir yansıması olan birey-çevre uyumu kuramına dayanmaktadır. Buna göre bireylerin tutum ve davranışları hem çevrenin hem de bireyin ortak etkisinin bir sonucudur (Edwards vd., 1998). Diğer bir ifadeyle tutum ve davranışlar ne sadece çevrenin ne de sadece bireyin tercihlerinin sonucudur. Birey 
çevreden etkilendiği gibi aynı zamanda içinde bulunduğu çevreyi de etkileyebilmektedir.

Birey-çevre uyumu kuramına göre bireyler kendi değerleriyle uyumlu çevrelerde bulunmayı tercih eder ve bu çevrelerde başarılı olurlar. Benzer şekilde bir çalışan da, istek ve ihtiyaçlarının karşılandığı bir örgütte çalışmayı tercih edip (Caplan, 1987) böyle bir örgütteki yapı ve uygulamalara olumlu tutumsal ve davranışsal tepkiler verebilecektir. Birey ve örgütün benzer değerlere sahip olması, aralarındaki iletișimin güçlü olmasını, daha az belirsizlik ve çatışma olmassını sağlayacak bu da iş tatminini artıracaktır (Meydan, 2019). Görgül araştırmalar da, yüksek birey-örgüt uyumunun örgütsel bağlılık, iş tatmini ya da örgütsel vatandaşlık davranışı gibi olumlu sonuçlara yol açtığını doğrulamaktadır (Cable ve Judge, 1994; Cable ve Judge, 1996; Zhao, 2009). Ng ve Burke (2005) birey-örgüt uyumunun, bireyin iş tercihinde en önemli faktör olduğunu bulmuştur. Tersine birey-örgüt uyumu azaldıkça işten ayrılma niyeti ve stres gibi olumsuz sonuçlar ortaya çıkabilmektedir (Zhang, 2005; Liu vd., 2010).

Konuyla ilgili Türkiye'de yürütülen çalışmalara bakıldığında ise yabancı yazınla paralel şekilde birey-örgüt uyumunun çalışanların örgütsel bağlılıklarını (İplik vd., 2011; Özcan, 2012; Alnıaçık vd. 2013, Yücel ve Çetinkaya, 2016), örgütsel vatandaşlık davranıșlarını (Akbaș, 2011; Polatçı ve Cindiloğlu, 2013), iş tatminlerini (İplik vd., 2011; Özcan, 2012; Alnıaçık vd. 2013; Kılıç ve Yener, 2015) arttırdığı, buna karşılık çalışanın işe yönelik stresini (Yıldırım ve Torun, 2007; Ulutaş, 2011; Kılıç ve Yener, 2015) ve işten ayrılma niyetini (Uysal, 2014; Sıpahi ve Kesen, 2016) azalttığı görülmektedir. Meglino ve Ravlin (1998) değerlerin uyumu olarak ele aldıkları Uyum Modelinde değer uyumunun bireylerin tutum ve davranışlarını olduğu kadar algılarını da etkileyeceğini ifade etmektedir. 0 halde yüksek düzeydeki birey-örgüt uyumunun çalıșanların örgütsel adalet algılarını da etkileyeceği düşünülebilir.

Diğer taraftan örgütsel adalet yazınında, dağıtım, prosedür ve etkileşim adaleti gibi örgütsel adalet boyutlarının bireysel ve örgütsel konularla farklılaşan ilişkilere sahip olduğu ifade edilmektedir (Konovsky ve Cropanzano, 1991; Cohen-Charash ve Spector, 2001; Masterson vd., 2000). Örneğin, Konovsky ve Cropanzano (1991) çalışan performansının en önemli belirleyicisinin prosedür adaleti olduğunu öne sürerken, Masterson vd. (2000) etkileșim adaletinin ön plana çlkan etkisinden bahsetmektedir. Bu sonuçlardan hareketle de birey-örgüt uyumunun örgütsel adalet üzerindeki etkisinin şiddetinin, örgütsel adaletin boyutları bazında farklılaşabileceği de beklenebilir.

Yukarıda yapılan açıklamalar doğrultusunda örgütsel adaletin boyutları bazında geliștirilen hipotezler aşağıdaki gibidir:

H1: Birey-örgüt uyumu düzeyinin çalışanların dağıtım adaleti algıları üzerinde pozitif yönde bir etkisi vardır.

H2: Birey-örgüt uyumu düzeyinin çalışanların prosedür adaleti algıları üzerinde pozitif yönde bir etkisi vardır.

H3: Birey-örgüt uyumu düzeyinin çalıșanların kişilerarası adalet algıları üzerinde pozitif yönde bir etkisi vardır.

H4: Birey-örgüt uyumu düzeyinin çalışanların bilgilendirmeye dayalı adalet algıları üzerinde pozitif yönde bir etkisi vardır.

\section{ARAŞTIRMANIN YÖNTEMİ}

\subsection{Veri toplama araçları}

Birey-örgüt uyumunun, çalışanların örgütsel adalet algıları üzerinde nasıl bir etkisinin olduğu incelenen bu araștırmada veri toplama aracl olarak anket yöntemi tercih edilmiştir. Çalışmada kullanılan anket, çalışanların örgütsel adalet algıları, birey-örgüt uyumu algıları ve katılımcıların demografik özellikleri ile ilgili veri elde etmeye yönelik ifadelerden oluşmaktadır.

Çalışanların adalet algısı, Colquitt (2001) tarafından geliştirilen ve daha önce Türkiye'de pek çok araștırmada kullanılan (Özmen vd., 2007; Yürür ve Demir, 2011, Yürür ve Mengenci, 2014; Yürür ve Nart, 2016) örgütsel adalet ölçeği ile ölçülmüştür. Ölçek dağıtım, 
prosedür, kişilerarası ve bilgilendirmeye dayalı adalet olmak üzere örgütsel adaletin 4 boyutunu ölçen 20 sorudan oluşmaktadır. "İsyerinizdeki süreçler doğru bilgiye dayandırılmış mıdır?", "Elde ettiğiniz kazanımlar işteki çabanızı yansitır mı?", "Yöneticiniz süreçleri bütünüyle açıllar mı?" ve "Yöneticiniz size nazik davranır mı?" bu ölçekte yer alan sorulara örnektir.

Araştırmanın bağımsız değişkeni olan bireyörgüt uyumu düzeyi, Netemeyer vd. (1997) tarafından geliştirilen ve Türkiye'de Turunç ve Çelik (2012) tarafından kullanılan 4 ifadelik ölçek kullanılarak ölçülmüştür. "Bu işletmenin değerleri ile kişisel değerlerimin uyumlu olduğunu düşünüyorum." ve "Bu işletmenin dürüstlük konusundaki değerleri ile benim değerlerim aynıdır." bu ölçekte yer alan ifadelere örnektir.

Çalışmada kullanılan her iki ölçekte yer alan ifadelere 5'li Likert formatında yanit istenmiştir, buna göre " $5=$ Kesinlikle Katılıyorum"; "1=Kesinlikle Katılmıyorum"u ifade etmektedir.

\subsection{Katılımcı profili}

Araştırma, Eylül-2016 ile Şubat-2017 arasında Yalova'da devam etmiş olup, veriler kamu ve özel sektör çalışanlarından elde edilmiştir. Başlangıçta 270 anket dağıtılmış, 235'i geri dönmüş ve geri dönen anketlerden 220 tanesinin analiz için uygun olduğu görülmüştür.

Örneklem grubu, cinsiyet açısından eşit dağılıma sahip olup 110 kadın ve 110 erkek çalışandan oluşmaktadır. Ankete katılanların demografik verileri incelendiğinde \%60'ının evli olduğu, \%27' sinin 18-30 yaş aralı̆̆ında olduğu, \%35'inin ise 31-40 yaş aralığında olduğu, \%19'unun 41-50 yaş aralığında olduğu, \%13'ünün 51-60 yaş aralı̆̆ında olduğu ve $\% 1$ 'nin 60 ve üzeri yaş aralığında olduğu görülmüştür. Araştırma kapsamındaki çalışanın \%48'i kamu çalışanı, geri kalanı \%50'si ise özel sektör çalışanıdır. Örgüt içindeki pozisyonları açısından \%72 gibi önemli bir çoğunluğun yöneticilik görevi olmayan çalışanlardan oluştuğu görülmüştür.
Katılımclların eğitim düzeylerine bakıldığında, \%4'ünün ilkokul, \%19'unun lise mezunu, \%25'inin yüksekokul, \%38'inin lisans ve \%11'inin yüksek lisans mezunu olduğu görülmektedir. Son olarak 1-10 yll çalışma süresine sahip çalışanların oranının \%62, 1120 yıl çalıșma süresine sahip çalışanların oranının \%17, 21-30 çalışma süresine sahip çalışanların oranının $\% 12$ ve 30 yıl ve üzeri çalışma süresine sahip çalışanların oranının \%1 olduğu tespit edilmiştir.

\subsection{Veri analizi}

Araștırmada veri analizi SPSS paket programı kullanılarak gerçekleștirilmiştir. Bu doğrultuda öncelikle katılımcıların demografik özelliklerine yönelik bulguların elde edilmesi için frekans analizi yapılmıştır. Ardından araştırmada kullanılan örgütsel adalet ve bireyörgüt uyumu değişkenleri için faktör analizi ve güvenilirlik testi yapılmıştır. Daha sonra da değișkenlerin arasındaki ilişkilerin açıklanması için korelasyon ve regresyon analizleri yapılmıştır.

\subsubsection{Faktör analizi}

Araştırma öncesinde ölçekte yer alan ifadelere ilişkin yanlış anlaşılmaları en aza indirmek, ölçeklerin faktör yapılarını ve güvenilirliklerini test etmek amacıyla 40 katılımcıdan oluşan bir gruba yönelik pilot çalışma yapılmıştır. Elde edilen 40 anket formuyla yapılan faktör analizinde örgütsel adalet ölçeğinin 4 faktörlü bir yapı gösterdiği (dağıtım adaleti algısı, prosedür adaleti algısı, kişilerarası adalet algısı ve bilgilendirmeye dayalı adalet algisı) ve birey-örgüt uyumu ölçeğinin ise tek faktörlü bir yapı gösterdiği görülmüștür. Pilot çalışma için oluşan faktör yapıları içsel tutarlılık analizine tabi tutulmuştur. Elde edilen analiz sonucunda dağıtım adaletinin $\alpha$ katsayısının .89 , prosedür adaletinin $\alpha$ katsayısının .80, kişilerarası adaletin $\alpha$ katsayısının .89 , bilgilendirmeye dayalı adaletin $\alpha$ katsayısının .85 ve bireyörgüt uyumunun $\alpha$ katsayısının ,94 olduğu tespit edilmiştir. Araştırmada kullanılan değişkenlerin tamamının Cronbach's Alfa değerinin sosyal bilimlerce kabul edilen .70'den 
(Nunnally, 1978) büyük olduğu tespit edilmiş ve anket mevcut haliyle diğer katılımcılara ulaştırılarak araştırmaya devam edilmiştir. Örneklemin tamamından elde edilen veri setine Varimax rotation kullanılarak, faktör yükü 0,50'nin altında olanlar elenerek (Hair vd., 2010) açıklayıcı faktör analizi yapılmıştır. KMO değerinin ,885 olduğu ve Bartlett küresellik derecesinin de anlamlı olduğu tespit edilmiş $(p<01)$ ve veri setinin faktör analizi için uygun olduğuna karar verilmiştir. Yapılan faktör analiziyle oluşan 5 faktörlü yapının toplam varyansının .71'ini açıklayabildiği görülmüștür. Faktör analizine ilişkin sonuçlar Tablo 1'de yer almaktadır.

\section{Tablo 1: Faktör analizi}

Faktör analizi sonucunda örgütsel adalet ölçeğinin 4 faktörlü, birey-örgüt uyumunun ise tek faktörlü bir yapı sergilediği görülmüştür. Faktör analiziyle ortaya çıkan bu yapının Colquitt (2001) tarafından geliştirilen örgütsel adalet ölçeğine ve Netemeyer vd. (1997) tarafından geliştirilen birey-örgüt uyumu ölçeğine uygun bir yapı sergilediği gözlemlenmiștir.

Faktör analizine ilişkin sonuçların yer aldığ Tablo 1'de, koralesyon analizi sonuçlarının yer aldığı Tablo 3'te ve regresyon analizine ilişkin sonuçların yer aldığı Tablo 4'te araştırmada kullanılan değişkenler için kısaltmalar yapılmıştır. Buna göre ÖA: Örgütsel Adalet, BÖU: Birey-Örgüt Uyumu, DA: Dağıtım Adaleti, PA: Prosedür Adaleti, KA: Kişilerarası Adalet, BA: Bilgilendirmeye Dayalı Adalet'i ifade etmektedir.

\subsubsection{Araştırmanın güvenilirliği}

Faktör analizi sonucunda oluşan faktör yapılarının güvenilirliğinin test edilmesi amacıyla içsel tutarlılık analizi yapılmıştır. İçsel tutarlık analizinde Cronbach's Alfa değerine bakılmış ve elde edilen değerler Tablo 2'de verilmiştir.

Tablo 2: Değişkenlerin cronbach's alfa değerleri

\begin{tabular}{lcc}
\hline Değişkenler & İfadeSayısı & $\begin{array}{c}\text { Cronbach's } \\
\text { Alfa }\end{array}$ \\
\hline $\begin{array}{l}\text { Birey-Örgüt } \\
\text { Uyumu }\end{array}$ & 4 &, 93 \\
\hline Dağıtım Adaleti & 7 &, 92 \\
\hline Prosedür Adaleti & 4 &, 85 \\
\hline $\begin{array}{l}\text { Kişilerarası } \\
\text { Adalet }\end{array}$ & 4 &, 90 \\
\hline $\begin{array}{l}\text { Bilgilendirmeye } \\
\text { Dayalı Adalet }\end{array}$ & 5 &, 89 \\
\hline
\end{tabular}

Yapılan güvenilirlik analiziyle, birey-örgüt uyumuna ilişkin $\alpha$ katsayısının .93, dağıtım adaletine ilişkin $\alpha$ katsayısının .92, prosedür adaletine ilişsin $\alpha$ katsayısının .85, kişilerarası adalete ilişkin $\alpha$ katsayısının .90 ve bilgilendirmeye dayalı adalete ilişkin $\alpha$

\begin{tabular}{|c|c|c|c|c|c|}
\hline \multirow[b]{2}{*}{ İfadeler } & \multicolumn{5}{|c|}{ Faktör Yükleri } \\
\hline & PA & DA & KA & BA & B-ÖU \\
\hline PA1 & ,542 & & & & \\
\hline PA2 & 660 & & & & \\
\hline PA3 & 693 & & & & \\
\hline PA4 & ,763 & & & & \\
\hline PA5 & ,727 & & & & \\
\hline PA6 & ,705 & & & & \\
\hline PA7 & 664 & & & & \\
\hline DA1 & & 890 & & & \\
\hline DA2 & & 849 & & & \\
\hline DA3 & & 895 & & & \\
\hline DA4 & & 846 & & & \\
\hline KA1 & & & 834 & & \\
\hline KA2 & & & 834 & & \\
\hline KA3 & & & 846 & & \\
\hline KA4 & & & 705 & & \\
\hline BA1 & & & & 567 & \\
\hline BA2 & & & & 794 & \\
\hline BA3 & & & & 778 & \\
\hline BA4 & & & & 696 & \\
\hline BA5 & & & & 829 & \\
\hline B-ÖU1 & & & & & ,818 \\
\hline B-ÖU2 & & & & & ,876 \\
\hline B-ÖU3 & & & & & ,903 \\
\hline B-0̈U4 & & & & & 860 \\
\hline Özdeğer & 8,9 & 2,3 & 1,9 & 1,1 & 2,9 \\
\hline $\begin{array}{l}\text { Açıklanan } \\
\text { Varyans (\%) }\end{array}$ & 37,2 & 9,5 & 8,0 & 4,6 & 12,3 \\
\hline Açıklanan T & am Var & ans (\%) & & & 71,8 \\
\hline
\end{tabular}


araștırmada kullanılan değișkenlerin tamamının $\alpha$ katsayısı .70 sınırının üzerinde olduğu için elde edilen boyutların araştırma için güvenilir olduğu kanısına varılmıştır.

\subsubsection{Betimleyici istatistikler ve korelasyon değerleri}

$\mathrm{Bu}$ bölümde araştırmanın değişkenlerine ait ortalama, standart sapma ve değişkenler arasındaki ilişkinin tespit edilmesi için korelasyon analizi sonuçlarına yer verilmiştir (Tablo 3). Araştırmada kullanılan dört bağımlı değişkenin hem kendi aralarındaki hem de birey-örgüt uyumu arasındaki ilişkinin pozitif ve anlamlı olduğu korelasyon analizi sonucunda ortaya çıkmıştır $(\mathrm{p}<0,01)$. Ayrıca birey-örgüt uyumu ile en yüksek ilişkiye prosedür adaletinin sahip olduğu $(r=, 457)$ ve bunu da bilgilendirmeye dayalı adaletin izlediği görülmektedir $(\mathrm{r}=, 417)$.

Tablo3: Betimleyici istatistikler ve korelasyon değerleri

\begin{tabular}{llllll}
\hline Değişkenler & B-ÖU & DA & PA & KA & BA \\
\hline B-ÖU & 1 & & & & \\
DA &, $333^{*}$ & 1 & & & \\
PA & $\mathbf{4 5 7}^{*}$ &, $363^{*}$ & 1 & & \\
KA &, $325^{*}$ &, $292^{*}$ &, $392^{*}$ & 1 & \\
BA & $\mathbf{4 1 7}^{*}$ &, $205^{*}$ &, $517^{*}$ &, $651^{*}$ & 1 \\
\hline Ort. & $\mathbf{3 , 1 7}$ & 3,37 & 3,43 & $\mathbf{3 , 7 2}$ & 3,68 \\
\hline S.S. & 1,11 & 1,15 &, 78 &, 90 &, 87 \\
\hline $\mathbf{N}$ & 220 & 220 & 220 & 220 & 220 \\
\hline
\end{tabular}

Tablo 3'te yer alan değişkenlere ilişkin betimleyici istatistiklere bakıldığında, örgütsel adalet alt boyutlarının içinde en yüksek ortalamaya sahip boyutun $(3,72)$ kişilerarası adalet olduğu görülmektedir. Birey-örgüt uyumunun ortalaması ise 3,17 'dir.

\subsection{Araștırmanın bulguları}

Araștırmanın hipotezlerinin test edilebilmesi amacıyla birey-örgüt uyumunun bağımsız, her bir örgütsel adalet boyutunun bağımlı değişken olarak belirlendiği dört basit regresyon analizi yapılmıştır. $\mathrm{Bu}$ analizler sonucunda elde edilen bulgular Tablo 4'te özetlenmiştir.
Tablo 4'te görülebileceği gibi regresyon analizleri sonuçlarına göre birey-örgüt uyumu tüm örgütsel adalet boyutlarını istatistiksel olarak anlamlı düzeyde etkilemektedir $(p<0,01)$. Beta katsayılarına bakıldığında bireyörgüt uyumunun en güçlü etkisi, prosedür adaleti üzerinedir $(0,457)$. Buna göre prosedür adaletindeki değişimin \%20'si birey-örgüt uyumu tarafından açıklanmaktadır $\left(R^{2}=0,20\right)$. İkinci en yüksek düzeyde etkilenen bağıml değişkenin ise bilgilendirmeye dayalı adalet olduğu görülmektedir $(0,417)$. Birey-örgüt uyumu ayrıca diğer örgütsel adalet boyutları olan dağıtım ve kişilerarası adalet boyutlarını da istatistiksel olarak anlamlı bir şekilde etkilemektedir ve iki bağımlı değişkene ilișkin beta katsayılarının birbirine yakın olduğu görülmektedir (dağıtım adaleti için: ,333; kişilerarası adalet için: 0,325).

Tablo 4: Birey-örgüt uyumu ile örgütsel adalet boyutları arasında yapılan basit regresyon analizleri özeti

\begin{tabular}{l|c|c|c|c}
\hline & $\begin{array}{c}\text { DA } \\
\text { (Model1) }\end{array}$ & $\begin{array}{c}\text { PA } \\
\text { (Model2) }\end{array}$ & $\begin{array}{c}\text { KA } \\
\text { (Model3 } \\
\text { ) }\end{array}$ & $\begin{array}{c}\text { BA } \\
\text { (Model4 } \\
\text { ) }\end{array}$ \\
\hline $\mathbf{B}$ &, 344 &, 321 &, 265 &, 328 \\
\hline $\begin{array}{l}\text { Bet } \\
\mathbf{a}\end{array}$ &, 333 &, 457 &, 325 &, 417 \\
\hline $\mathbf{T}$ & 5,216 & 7,580 & 5,077 & 6,766 \\
\hline $\mathbf{p}$ &, $000^{*}$ &, $000^{*}$ &, $000^{*}$ &, $000^{*}$ \\
\hline
\end{tabular}

\begin{tabular}{l|c|c|c|c}
\hline $\mathbf{R}^{\mathbf{2}}$ &, 111 &, 209 &, 106 &, 174 \\
\hline $\mathbf{D . R ^ { 2 }}$ &, 107 &, 205 &, 102 &, 170 \\
\hline $\mathbf{F}$ & 27,21 & 57,46 & 25,778 & 45,778 \\
& 1 & 3 & & \\
\hline $\mathbf{p}$ &, $000^{*}$ &, $000^{*}$ &, $000^{*}$ &, $000^{*}$ \\
\hline
\end{tabular}

Bağımsız Değisşken: Birey-Örgüt Uyumu $* \mathrm{p}<0,01$

\section{DEĞERLENDİRME VE SONUÇ}

Araştırmada elde edilen bulgular doğrultusunda öncelikle yüksek düzeyde bireyörgüt uyumunun örgütsel adalet algısını artırdığı söylenebilir. Diğer bir anlatımla, çalışanların değerleriyle örgütsel değerler arasında bir uyum olduğunda, çalışanlar 
örgütteki kaynak dağılımını, bu kararlara yol açan prosedürleri ve tüm bu süreçlerdeki ilişkileri daha adil algılamaktadır. Bu sonuç, birey ve örgüt arasında uyum olduğunda, bireylerin içinde yer aldıkları örgütsel ortama olumlu tepkiler vereceğini öne süren bireyörgüt uyumu kuramını da (Kristof, 1996) desteklemektedir. Bireylerin göstereceği olumlu tepkilerden birinin de örgütü daha adil algılamak olduğu söylenebilir. Bu sonuç aynı zamanda, birey-örgüt uyumunun olumlu sonuçlarına vurgu yapan diğer görgül araștırma sonuçlarıyla da tutarlılık göstermektedir (Lauver ve Kristof-Brown, 2001; Silverthorne, 2004; Kristof-Brown vd., 2005). Aynı zamanda bu araştırmada bireyörgüt uyumunun örgütsel adalet üzerindeki etkisinin, tüm boyutları bazında anlamlı olması, bu uyumun örgütsel adalet olgusunun anlaşılması ve açıklanmasında önemli bir konu olduğunu da göstermektedir.

Esasen birey-örgüt uyumunun örgütsel adalet algısına etkisine dair bu araştırmada elde edilen bulgular, örgütsel adalet yazınında var olan bazı yaklaşım ve modellerin de açıklanmasına katkı sağlar niteliktedir. "Bireyler için örgütsel adalet neden önemlidir?" ya da "bireyler hangi güdülerle adalete değer atfetmektedir?" sorularına yanıt bulmak amacıyla geliştirilen modellerden biri kişisel çlkar modelidir (Lind ve Tyler, 1988; Tyler ve Lind, 1992). Araçsal model olarak da adlandırılan kişisel çıkar modeline göre insanlar için adalet önemlidir çünkü adalet, gelecekte elde edilecek kazanımların bir garantisidir (Blader ve Tyler, 2003). Diğer bir deyişle eğer örgüt içinde adalet olmazsa bireyler için bu, ileride kendi kazanımlarının da riske gireceği anlamına gelmektedir. 0 halde adalet bireylerin kısa ya da uzun dönem çıkarları için önemlidir ve insanların adaletle ilgilenmelerinin nedeni kişisel çıkarlarıdır. $\mathrm{Bu}$ araştırmada elde edilen sonuçlar da bu modeli doğrular niteliktedir.

Birey-örgüt açısından tarafların birbiriyle uyumlu olan değerleri etik standartlara aykırı ise? Yine de birey örgütsel değerlere dayalı olarak ortaya çıkan uygulamaları adil algılar mı? En azından bu çalışmada elde edilen sonuçlara göre bu sorunun cevabı, kısmen evet. Yani örgütsel değerlerin etik olmasından bağımsız olarak, bireyin değerleri ile uyumlu olduğu takdirde çalışanlara göre örgütte adalet vardır. Bu sonuç da bizi, uyum her zaman iyi midir sorusuna yönlendirmektedir. Meglino ve Ravlin (1998) benzer bir tartışmayı, birey ve örgüt arasındaki yüksek düzeyde uyum, örgütün çevreyle uyumunu azaltarak rekabet gücünü zayıflatıyorsa olumsuz olacağı konusunda yapmaktadır. 0 halde adalet algısını şekillendiren bir olgu olarak uyum iyi olmayabilir ya da kimin için iyi sorusu gündeme gelmektedir. Her ne kadar burada uyumun örgütsel adalet algısını artırdığı tespit edilmiş olsa da bu etkinin düzeyi sınırlıdır (prosedür adaleti için \%20). Yani bu bulgu, adalet algısını etkileyen başka değişkenlerin de varlığına işaret etmektedir. Bunlardan biri de bireylerin etik değerleri ve standartları olabilir. $\mathrm{Bu}$ nedenle daha sonra yapılacak araştırmalarda, adalet algısının öncülü olarak birey-örgüt uyumunun yanı sira özellikle bireyin etik değerleri ve standartlarının da modele dahil edilmesi, bir karşılaştırma yapma olanağı sağlaması açısından önemlidir.

$\mathrm{Bu}$ araştırmanın öne çıkan bir başka sonucu ise birey-örgüt uyumunun, diğer örgütsel adalet boyutlarına göre prosedür adaleti algısı üzerindeki göreli güçlü etkisidir. $\mathrm{Bu}$ göreli güçlü etkinin cevabı belki de bu iki değişkenin tanımında yatmaktadır. Prosedür adaleti örgütsel kaynakların dağıtımında kullanılan prosedürlere ilişkin adalet algısıdır (Folger ve Konovsky, 1989). Diğer taraftan birey-örgüt uyumu ise bireysel ve örgütsel değerler arasındaki uyum olduğuna göre (Chatman, 1989), prosedürlerin diğer örgütsel adalet boyutlarına nazaran örgütün değer ve karakteristiklerini daha fazla yansıtıyor olması doğal karşılanabilir. Çalışanlar örgütsel değerleri en fazla örgütsel prosedür ve uygulamalarda hissediyor ve kendi değerleri ile karşılaştırma yaparken de en fazla bu prosedürleri dikkate alıyor olabilirler.

$\mathrm{Bu}$ araştırmada elde edilen sonuçların hem örgütsel adalet yazınındaki modellere sağladığı 
İzmir İktisat Dergisi (İzmir Journal of Economics) , Yıl:2019 Cilt:34 Sayı:2 ss. 213-224

katkı hem de birey-örgüt uyumu kuramına sağladığı katkı açısından önemli olduğu düşünülebilir. Gelecekte yapılacak çalışmalar için, birey-örgüt uyumunun örgütsel adalete etkilerinin etik değerleri de içerecek şekilde, 'neden' ve 'nasıl'larının ele alındığı araștırmalarla konunun daha derinlemesine analiz edilmesi önerilebilir.

\section{KAYNAKÇA}

Adams, J.S. (1965). Inequity in Social Exchange. Advances in Experimental Social Psychology, 2, 267-299.

Akbaş, T. T. (2011). Algllanan Kişi-Örgüt Uyumunun Örgütsel Vatandaşlık Davranışları Üzerindeki Etkisi: Görgül Bir Araştırma. Yönetim Bilimleri Dergisi, 9(1), 55-81.

Alnıaçık, E., Alnıaçık, Ü., Erat, S. ve Akçin, K. (2013). Does Person-Organization Fit Moderate The Effects of Affective Commitment and Job Satisfaction on Turnover Intentions? Procedia-Scialand Behavioral Sciences, 99, 274-281.

Bies, R. J. ve Moag, J. S. (1986). Interactional Justice: Communication Criteria of Fairness. Research on Negotiations in Organizations, 1, 43-55.

Blader, S. L. ve Tyler, T. R. (2003). What Constitutes Fairness in Work Settings? A FourComponent Model of Procedural Justice. Human Resource Management Review, 13(1), 107-126.

Cable M. D. ve Judge, T. A. (1994). PayPreferences and Job Search Decisions: A Person Organization Fit Perspective. Personel Psychology, 47, 317-349.

Cable M. D. ve Judge, T. A. (1996). Person-Organization Fit, Job Choice Decisions and Organizational Entry. Organizational Behavior and Human Decision Processes, 67(3), 294-311.

Cable M. D. ve Edwards, J. R. (2004). Complementary and Supplementary Fit: A Theoretical and Empirical İntegration. Journal of Applied Psychology, 89(5), 822-834.

Caplan, D. R. (1987). PersonEnvironment Fit Theory and Organizations: Commensurate Dimensions, Time Perspectives, and Mechanisms. Journal of Vocational Behavior, 31(3), 248-267.

Chatman, J. A. (1989). Improving Interactional Organizational Research: A Model of Person Organization Fit. Academy of Management Review, 14(3), 333-349.

Colquitt, J. A. (2001). On the Dimensionality of Organizational Justice: A Construct Validation of A Measure. Journal of Applied Psychology, 86(3), 386-400.

Cohen-Charash, Y. ve Spector, P. E. (2001). The Role of Justice in Organizations: A Meta-Analysis. Organizational Behavior and Human Decision Processes, 86(2), 278-321.

Cropanzano, R., Goldman, B. ve Folger, R. (2003). Deontic Justice: The Role of Moral Principles in Workplace Fairness. Journal of Organizational Behavior, 24(8), 1019-1024.

Çelik, M., Turunç, Ö. ve Demirkaya, H., (2011). Çalışanların Adalet Algılarının İş Performansına Etkisinde Kişi Örgüt Uyumunun Aracilık Rolü: Turizm Sektöründe Görgül Bir Çalışma. SOID-Seyahat ve Otel İşletmeciliği Dergisi, 8(2), 47-50.

Edwards, J. R., Caplan, R. D. ve Harrison, R. V. (1998). Person-Environment Fit Theory: Conceptual Foundations, Empirical Evidence, and Directions for Future Research. Theories of Organizational Stress, (Ed. C. L. Cooper), Oxford: Oxford University Press, 28-67.

Edwards, J. R. ve Shipp, A. J. (2007). The Relationship Between Person Organizational Fit and Outcomes: An Integrative Theoretical Framework. Perspectives on Organizational Fit, (Ed. C. Ostroff, T. A. Judge), New York: Lawrence Erlbaum Associates, USA, 209-258.

Folger, R. ve Cropanzano, R. (1998). Organizational Justice and Human Resource Management, Beverly Hills, CA: Sage Publications, USA.

Folger, R. ve Konovsky, M. A. (1989). Effects of Procedural and Distributive Justice on Reactions to Pay Raise Decisions. Academy of Management Journal, 32(1), 115-130.

Fox, S., Spector, P. E. ve Miles, D. (2001). Counterproductive Work Behavior 
(CWB) in Response to Job Stressors and Organizational Justice: Some Mediator and Moderator Tests for Autonomy and Emotions. Journal of Vocational Behavior, 59(3), 291-309.

Greenberg, J. (1990). Employee Theft as a Reaction to Underpayment Inequity: The Hidden Cost of Paycuts. Journal of Applied Psychology, 75(5), 561-568.

Greenberg, J. (1993). The Social Side of Fairness: Interpersonal and Informational Classes of Organizational Justice. Justice in the Workplace: Approaching Fairness in Human Resource Management, (Ed. R. Cropanzano) Lawrence Erlbaum Associates, Publishers, New Jersey, 79-103.

Hair, J. F., Black, W. C., Babin, B. J. ve Anderson, R. E. (2010). Multivariate Data Analysis, 7th Ed. Pearson Prentice Hall, New Jersey.

İplik, F. N., Kılıç, K. C. ve Yalçın, A. (2011).

The Simultaneous Effects of

Personorganization and Person-Job Fit on Turkish Hotel Managers. International Journal of Contemporary Hospitality Management, 23(5), 644-661.

Kılıç, K. C. ve Yener, D. (2015). BireyÖrgüt ve Birey-İş Uyumunun Çalışanların İş Tutumlarına Etkisi: Adana İlinde Bankacılık Sektöründe Çalışanlar Üzerine Bir Araştırma. Ç.Ü. Sosyal Bilimler Enstitüsü Dergisi, 24(1), 161-174.

Konovsky, M. A. ve Cropanzano, R. (1991). Perceived Fairness of Employee Drug Testing As a Predictor of Employee Attitudes and Job Performance. Journal of Applied Psychology, 76(5), 698-707.

Konovsky, M. A. ve Organ D. W. (1996). Dispositional and Contextual Determinants of Organizational Citizenship Behavior. Journal of Organizational Behavior, 17(3), 253 -266.

Köksal, K. (2017). Kişi Örgüt Uyumunun Örgütsel Adalet Algısı ve Örgütsel Bağlılık İlişkisinde Aracılık Rolü. Savunma Bilimleri Dergisi, 16(2), 37-58.

Kristof, A. L. (1996). PersonOrganization Fit: an Integrative Review of its
Conceptualizations, Measurement, and Implications. Personnel Psychology, 49, 1-49.

Kristof-Brown, A. L., Zimmerman, R. D. ve Johnson, E. C. (2005). Consequences of Individuals'fit At Work: A Meta-Analysis of Person-Job, Person-Organızatıon, PersonGroup, and Person-Supervisor Fit. Personnel Psychology, 58(2), 281-342.

Lauver, K. J. ve Kristof-Brown, A. (2001) Distinguishing Between Employees' Perceptions of Person-Job And PersonOrganization Fit. Journal of Vocational Behavior, 59(3), 454-470.

Lavelle, J. J., Brockner, J., Konovsky, M. A., Price, K. H., Henley, Amy B., Taneja, A. ve Vinekar, V. (2009). Commitment, Procedural Fairness, and Organizational Citizenship Behavior: A Multifoci Analysis. Journal of Organizational Behavior, 30(3), 337-357.

Lind, E. A. ve Tyler, T. R. (1988). The Social Psychology of Procedural Justice. New York: Plenum.

Liu, B., Liu, J. ve Hu, J. (2010). PersonOrganization Fit, Job Satisfaction and Turnover Intention: An Empirical Study in the Chinese Public Sector. Social Behavior and Personality, 39(5), 615-626.

Masterson, S. S., Lewis, K., Goldman, B. M. ve Taylor, M. S. (2000). Integrating Justice and Social Exchange: The Differing Effects of Fair Procedures and Treatment on Work Relationships. Academy of Management Journal, 43(4), 738-748.

Martin, C. L. ve Bennett, N. (1996). The Role Of Justice Judgments in Explaining The Relationship Between Job Satisfaction and Organizational Commitment. Group \& Organizational Management, 21(1), 84-104.

Mayer, D. M. ve Nishii, L. H., Schneider, B. ve Goldstein, H. (2007). The Precursors and Products of Justice Climates: Group Leader Antecedents and Employee Attitudinal Consequences. Personnel Psychology, 60(4), 929-963.

Mcfarlin, D. B. ve Sweeney, P. D. (1992). Distiributive and Procedural Justice As Predictors of Satisfaction With Personal and 
İzmir İktisat Dergisi (İzmir Journal of Economics) , Yıl:2019 Cilt:34 Sayı:2 ss. 213-224

Organizational Outcomes. Academy of Management Journal, 35(3), 36-49.

Meydan, B. T. (2019). Birey-Örgüt Uyumu ve Örgütsel Davranış Araştırmalarında Kuramsal Temel Olarak Kullanımı. Örgütsel Davranış Kuramları, (Ed. S. Yürür), Beta Yayınevi, İstanbul, 187-244.

Meglino B. M. ve Ravlin, E. C. (1998). Individual Values in Organizations: Concepts, Controversies, and Research. Journal of Management, 24(3), 351-389.

Moorman, R. H. (1991). Relationship Between Organizational Fairness and Organizational Citizenship Behaviors: Do Fairness Perceptions Influence Employee Citizenship?. Journal of Applied Psychology, 76(6), 845-855.

Muchinsky, P. M. ve Monahan, C. J. (1987). What Is Person-Environment Congruence? Supplementary Versus Complementary Models of Fit. Journal of Vocational Behavior, 31(3), 268-277.

Netemeyer, G. R., Boles, J. S., Mckee, D. 0. ve Mcmurrian, R. (1997). An İnvestigation into the Antecedents of Organizational Citizenship Behaviours in a Personal Selling Context. Journal of Marketing, 61(3), 85-98.

Ng, E. W.S. ve Burke, R. J. (2005). Person - Organization Fit and the War For Talent: Does Diversity Management Make a Difference? International Journal of Human Resource Management, 16(7), 1195-1210.

Nunnally, J. C. (1978). Psychometric Theory, (2. Baskı), McGraw-Hill, New York, USA.

Özcan, H. U. (2012). Birey-Örgüt Değerleri Arasındaki Uyumun Örgütle Özdeşleşme ile İlişkisi. Türk Psikoloji Yazıları, 15(29), 25-39.

Özmen, Ö. N. T., Arbak, Y. ve Özer, P. S. (2007). Adalete Verilen Değerin Adalet Algıları Üzerindeki Etkisinin Sorgulanmasına İliş̧kin Bir Araștırma. Ege Akademik Bakış, 7(1), 17-33.

Polatçı, S. ve Cindiloğlu, M., (2013). KişiÖrgüt Uyumunun Örgütsel Vatandaşlık Davranışına Etkisi: Duygusal Bağlılığın Aracılık Rolü. İktisadi ve İdari Bilimler Fakültesi Dergisi, 18(3), 299-318.
Sipahi, G. A. ve Kesen, M. (2016). The Effect Of Organizational Commitment On Person Organization Fit And Turnover Intention in Five Star Hotel. Eurasian Academy of Sciences Eurasian Business \& Economics Journal, 2, 340-352.

Silverthorne, C. (2004). The Impact of Organizational Culture and PersonOrganization Fit on Organizational Commitment and Job Satisfaction in Taiwan. Leadership \& Organization Development Journal, 25(7), 592-599.

Skarlicki, D. P. ve Folger, R. (1997). Retaliation in The Workplace: The Roles of Distributive, Procedural, and Interactional Justice. Journal of Applied Psychology, 82(3), 434-443.

Turunç, Ö. ve Çelik, M. (2012). İş Tatmini- Kişi-Örgüt Uyumu ve Amire GüvenKişi- Örgüt Uyumu İlişkisinde Dağıtım Adaletinin Düzenleyici Rolü. İş Güç Endüstri İlişkileri ve İnsan Kaynakları Dergisi, 14(2), S57-78.

Tyler, T. R. ve Lind, E. A. (1992). A Relational Model of Authority in Groups. Advances in Experimental Social Psychology, $25,115-191$.

Ulutaş, M. (2011). Birey-Örgüt Uyumunun İş Stresi ve Verimlilik Üzerine Etkisi: Dalaman Havalimanı Çalışanları Üzerine Bir Alan Araştırması. Selçuk Ünşversitesi Sosyal Bilimler Dergisi, 14(1-2) 13-29.

Uysal, D. I. (2014). Birey-Çevre Uyumu: Çalışanların Örgüt Uyumlarının Yaşama İlişskin Doyum ve İşten Ayrılma Niyetiyle İlişkisi. Türk Psikoloji Dergisi, 29(74), 34-45.

Ylldırım, E. B. ve Torun, A. (2007). Bireyİş Uyumu, Birey-Örgüt Uyumu ve Sosyal Desteğin, İş Stresi Üzerindeki Etkileri: Çağrı Merkezlerinde Bir Çalışma. XV. Ulusal Yönetim ve Organizasyon Kongresi, Sakarya, 171-178.

Yücel, İ. ve Çetinkaya, B. (2016). BireyÖrgüt Uyumu ile Örgütsel Bağlılık Arasındaki İlişkide Cinsiyetin Rolü: Kayseri Örneği. Aksaray Üniversitesi İktisadi ve İdari Bilimler Fakültesi Dergisi, 8(3).17-30.

Yürür, S. (2008). Örgütsel Adalet ile İş Tatmini ve Çalışanların Bireysel Özellikleri 


\section{N. YAZICI - S. YÜRÜR}

Arasındaki İlișkilerin Analizine Yönelik Bir Araştırma. SDÜ İktisadi ve İdari Bilimler Fakültesi Dergisi, 13(2), 295-312.

Yürür, S. (2015). Türkiyede Örgütsel Adalet Konusunda Yapılan Çalışmalara Yönelik Bir Derleme. Türkiye'de Örgütsel Davranış Araștırmaları-I (Ed. R. Özen Kutanis), Ankara: Gazi Kitapevi.

Yürür, S. (2018). Örgütsel Adalet. Çalışma Yaşamında Davranış Güncel Yaklaşımlar, (Ed., A. Keser, G. Yılmaz, S. Yürür), Umuttepe Yayınları, Kocaeli, 243-274.

Yürür, S. ve Demir, K. (2011). Örgütsel Adalet ve Psikolojik Güçlendirme: Karşılıklı Etkileri Üzerine Bir Araștırma. Süleyman Demirel Üniversitesi İktisadi ve İdari Bilimler Fakültesi Dergisi,16(3), 311-335.

Yürür, S. ve Mengenci, C. (2014). Örgütsel Adalet ve Ekstra Rol Davranışları İlişkisi. Yönetim ve Ekonomi Araştırmaları Dergisi, 24, 1-17.

Yürür, S. ve Nart, S. (2016). Örgütsel Adalet Algısı Kamu Çalışanlarının İhbar Etme (Whistleblowing) Niyetini Artırır mı?. Amme İdaresi Dergisi, 49(3), 117-148.

Zapata-Phelan, C. P., Colquitt, J. A., Scott, B. A. ve Livingston, B. (2009). Procedural Justice, Interactional Justice and Task Performance: The Mediating Role of Intrinsic Motivation. Organizational Behavior and Human Decision Processes, 108(1), 93-105.

Zhang, Y., Ying, G. ve Liu, P. (2005). Moderating Effects of P-O Fit in Turnover Intention Model: A Case of Foreign Pharmaceutical Companies in China. Nankai Business Review, 8(3), 37-41.

Zhao, H. (2009). The Effects of PersonalOrganization Fit and Organizational Citizenship Behaviort on Contextual Performance: An Empirical Research. Chinese Journal of Management, 6(3), 342-347. 